\title{
Molecular and Symptom Analyses of Phytoplasma Strains from Lettuce Reveal a Diverse Population
}

\author{
Jianhua Zhang, Saskia A. Hogenhout, Lowell R. Nault, Casey W. Hoy, and Sally A. Miller
}

First and fifth authors: Department of Plant Pathology; and second, third, and fourth authors: Department of Entomology, The Ohio State University, OARDC, 1680 Madison Ave., Wooster 44691.

Accepted for publication 3 April 2004.

\section{ABSTRACT}

Zhang, J., Hogenhout, S. A., Nault, L. R., Hoy, C. W., and Miller, S. A. 2004. Molecular and symptom analyses of phytoplasma strains from lettuce reveal a diverse population. Phytopathology 94:842-849.

Epidemics of aster yellows in lettuce in Ohio are caused by at least seven distinct phytoplasma strains in the aster yellows (AY) group. Five of the strains are newly reported: AY-BW, AY-WB, AY-BD3, AY-SS, and AY-SG. All seven strains were characterized based on symptoms in aster and lettuce, and by polymerase chain reaction (PCR). Strain AY-BD2 (formerly 'Bolt') causes yellowing and leaf distortion in lettuce and bolting in aster, whereas strain AY-S (formerly 'Severe') causes stunting, leaf clustering, and phyllody. Strain AY-WB causes yellowing and wilting in lettuce and witches'-broom in aster. Strain AY-SG induces horizontal growth in lettuce and aster plants. Strain AY-BW causes chlorosis of emerging leaves and abnormally upright growth of leaf petioles. AY-SS causes symptoms similar to those caused by AY-S but has a different PCR-restriction fragment length polymorphism (RFLP) banding pattern. Strains AY-BD2 and AY-BD-3 cause mild leaf and stem distortion in lettuce but are differentiated by PCR-RFLP. All phytoplasma strains collected from lettuce in Ohio belong to the 16SrI group. AY-WB belongs to the 16SrI-A subgroup and the other six belong to the 16SrI-B subgroup. Five of the seven strains were distinguished from each other by primer typing. The results of phylogenetic analyses of sequences of the 16S rRNA genes were basically consistent with the classification based on PCR-RFLP, in which AY-WB clustered with phytoplasmas of the 16rIA subgroup and the other Ohio lettuce strains clustered with phytoplasmas in the 16SrI-B subgroup.
Phytoplasmas are wall-less prokaryotes in the class Mollicutes that infect hundreds of plant species worldwide (25) and cause an array of host symptoms such as vein clearing, yellowing, stunting, and phyllody (20). They are obligate parasites transmitted by phloem-feeding leafhoppers. Aster yellows phytoplasmas (AYP) compose the largest of the phytoplasma groups classified to date (24). Epidemics of aster yellows in vegetable production areas in Ohio and other states in the north-central region of the United States are tied to the immigration of AYP-inoculative aster leafhoppers (Macrosteles quadrilineatus Forbes) in late spring and early summer from states to the south and west $(4,6,13)$. Locally produced leafhoppers acquire and spread AYP within and among host vegetable crops during the growing season. Aster yellows is a potentially devastating disease in lettuce (Lactuca sativa L.), with incidence varying from less than 1 to $100 \%$ from year to year in Ohio. A simulation model of aster yellows epidemics in Ohio demonstrated that the pattern of long range dispersal of inoculative leafhoppers, arrangement of host and nonhost crops in an area, and aster yellows latent period in host crops influences the severity of epidemics and yield loss (37). The structure of the model includes rates of AYP acquisition and transmission, as well as leafhopper development rates and latent periods in the plant and insect hosts. The presence of multiple AYP strains in the field could be responsible for the variation in symptoms observed. In addition, interactions among AYP strains in host plants and insect vectors may influence these variables.

AYP strains spread in host plants at different rates (17), which may influence acquisition efficiency by leafhoppers feeding on the plants and, subsequently, strain prevalence. In addition, leaf-

Corresponding author: S. A. Miller; E-mail address: miller.769@ osu.edu

Publication no. P-2004-0604-02R

(c) 2004 The American Phytopathological Society hoppers transmit different phytoplasma strains at different rates $(2,10,26)$. Further, Beanland et al. (1) found that AYP strains affected leafhopper fecundity differentially. Failure to culture phytoplasmas has hampered the identification, characterization, and detection of different strains. However, with the recent accumulation of phytoplasma genome sequence data (28), more molecular markers will be available, allowing differentiation of comparable strains by polymerase chain reaction (PCR). Because strain differences may influence development and persistence of aster yellows epidemics in plant hosts, better characterization of the variety of phytoplasma strains in the field is necessary. In this study, we characterized seven AYP strains collected from lettuce fields by host symptoms and molecular markers, including restriction fragment length polymorphism of PCR products (PCRRFLP) analysis and primer typing. Phylogenetic analyses also were conducted on the sequences of the 16S rRNA genes and the 16S-23S gene spacer regions of these AYP strains and those from the GenBank database.

\section{MATERIALS AND METHODS}

Aster leafhopper colony establishment and maintenance. A phytoplasma-free leafhopper colony was generated from $M$. quadrilineatus collected from Celeryville, $\mathrm{OH}\left(41.00^{\circ} \mathrm{N}, 82.45^{\circ} \mathrm{W}\right)$ in 1998. Adult leafhoppers were placed on oat (Avena sativa L.) seedlings in cages in a growth chamber at $25^{\circ} \mathrm{C}$ with a 16 -h day, 8-h night photoperiod. Females were allowed to oviposit on plants; then, second and third instars were transferred to oat seedlings not previously exposed to leafhoppers in a new cage and maintained as previously described (26). To insure that healthy leafhopper colonies were not infected by AYPs, leafhoppers of succeeding generations were tested by PCR using AYP-specific primers 16S F4 and R1 (5) in 20 bulk samples, each containing five leafhoppers. 
AYP strain isolation and maintenance. AYP isolates were collected from symptomatic lettuce plants in commercial fields in Celeryville, $\mathrm{OH}$ in 1998 and isolated in aster (Callistephus chinensis Nees) 'Matsumoto Red' plants (Stokes Seeds, Buffalo, NY). Field-collected isolates were designated with an "I" preceding the name. Symptomatic lettuce plants first were tested with phytoplasma universal primers P1 and P7 (35) and AYPspecific 16S rDNA primers F4 and R1 prior to leafhopper acquisition. Phytoplasma-positive lettuce plants were differentiated by symptoms and placed individually into separate nylon net cages and second- or third-instar aster leafhoppers were allowed a 4-day acquisition access period (AAP) in a growth chamber at $25^{\circ} \mathrm{C}$ with a 16-h day, 8-h night photoperiod. Following the AAP, lettuce plants were replaced with 3-week-old oat plants and the leafhoppers were maintained in the cage for 4 weeks, sufficient for completion of the latent period (26). The inoculative leafhoppers were transferred individually to 3-week-old healthy aster seedlings from an insect-free greenhouse for a 12-h inoculation access period (IAP). The inoculated seedlings then were transferred to an insect-free greenhouse with a day temperature of $25 \pm 2^{\circ} \mathrm{C}$ and a night temperature of $20 \pm 2{ }^{\circ} \mathrm{C}$ for symptom development. The infected aster plants were categorized according to symptoms. Plants with different symptoms were exposed individually to healthy leafhopper nymphs for a 12-h AAP as described above, followed by 4-week incubation of the leafhoppers and another 12 -h IAP by the inoculative leafhoppers on healthy aster plants. The cycle was repeated three times for all isolates. DNA was extracted from aster plants showing various symptoms and analyzed by PCR-RFLP as described below. After three cycles, each healthy aster plant was inoculated by four inoculative leafhoppers and the symptomatic plants were periodically analyzed (approximately every other month) using PCR-RFLP. Five plants were inoculated for each isolate. The isolated AYP strains were maintained by successive transfers between leafhoppers and aster plants or transferred by leafhoppers to romaine lettuce 'Parris Island Cos' (ASGROW Vegetable Seeds, Gonzales, CA) for symptom evaluation.

Determination of symptoms caused by AYP strains. Romaine lettuce Parris Island Cos plants were inoculated at approximately the 8- and 12-expanded-leaf stages. China aster 'Matsumoto Red' plants were inoculated at the 10-, 15-, and 20-expanded-leaf stages using AYP-inoculative leafhoppers. Aster plants inoculated at the 20-expanded-leaf stage did not show distinct symptom differences among the AYP strains and were not used for differentiation. The symptoms described herein are of aster plants infected at the 10- and 15-expanded-leaf stages and lettuce plants infected at 8- and 12-expanded-leaf stages. These are referred to as the early and late growth stages, respectively. Five plants were inoculated for each AYP strain and each plant by four to five inoculative leafhoppers in a nylon screen cage $(3.0 \mathrm{~cm}$ in diameter and $1.0 \mathrm{~cm}$ high). The side of the cage with nylon net was placed against the leaf surface and fixed with a clip so that the leafhoppers could feed through the holes. After a 72-h IAP, the cages with leafhoppers were removed and the plants were sprayed with insecticide (1100 Pyrethrum TR; Whitmire Micro-Gen Research Laboratories, St. Louis) and placed in a greenhouse (day temperature $25 \pm 2{ }^{\circ} \mathrm{C}$ and night temperature $20 \pm 2{ }^{\circ} \mathrm{C}$ ) for symptom development. Symptoms were evaluated twice, at early ( 20 days after initiation of IAP) and late (50 days after initiation of IAP) stages of infection. The host symptoms caused by different strains were compared with the appearance of uninfected plants, including leaf color and form, and branch and stem growth.

PCR-RFLP analysis. AYP DNA was extracted from plant or insect tissue using the cetyltrimethylammonium bromide method (36). The DNA was amplified by PCR using primers AY19p/ AY19m (30), P1/P7 (35), F2n/R2 (11), or F4/R1. The PCR reaction mixture contained the following: $1 \times$ PCR buffer $(200 \mathrm{mM}$ Tris- $\mathrm{HCl}, \mathrm{pH} 8.4$, and $500 \mathrm{mM} \mathrm{KCl}), 2.0 \mathrm{mM} \mathrm{MgCl}_{2}, 0.2 \mathrm{mM}$ dNTPs, $0.5 \mu \mathrm{M}$ each primers AY19p/AY19m, P1/P7, F2n/R2, or F4/R1, and 1.25 unit of Taq DNA polymerase in a final volume of $50 \mu \mathrm{l}$ for PCR-RFLP (or $25 \mu \mathrm{l}$ for detection). The PCR was conducted under the following conditions: $94^{\circ} \mathrm{C}$ for $2 \mathrm{~min}$; 30 cycles of $94^{\circ} \mathrm{C}$ for $30 \mathrm{~s}, 47^{\circ} \mathrm{C}$ (for AY $19 \mathrm{p} / \mathrm{AY} 19 \mathrm{~m}$ ), $55^{\circ} \mathrm{C}$ (for $\mathrm{BF} / \mathrm{BR}, \mathrm{AY}-\mathrm{WB}$ strain specific primers), or $50^{\circ} \mathrm{C}$ (for other primers) for $30 \mathrm{~s}$; and $72^{\circ} \mathrm{C}$ for $1.5 \mathrm{~min}$ (for $\mathrm{AY} 19 \mathrm{p} / \mathrm{AY} 19 \mathrm{~m}$, $\mathrm{P} 1 / \mathrm{P} 7$, or $\mathrm{F} 2 \mathrm{n} / \mathrm{R} 2$ ) or $1 \mathrm{~min}$ (for other primers), with a 10-min extension at $72^{\circ} \mathrm{C}$ following the last cycle in an Amplitron II thermal cycler (Barnstead/Thermolyne, Dubuque, IA) or a PTC100 programmable thermal controller (MJ Research, Waltham, MA).

For PCR-RFLP analysis, the 1.1-kb PCR products amplified with primers AY19p and AY19m were digested with DraI and the 1.2-kb PCR products amplified with primers $\mathrm{F} 2 \mathrm{n}$ and $\mathrm{R} 2$ were digested with AluI, RsaI, HhaI, and HaeIII at $37^{\circ} \mathrm{C}$ for $4 \mathrm{~h} \mathrm{(22).}$ The digested products were analyzed by electrophoresis in a $5 \%$ polyacrylamide gel at $3.5 \mathrm{~V} / \mathrm{cm}$ gel in $1 \times$ Tris-borate EDTA (TBE) buffer $(\mathrm{pH} 8.0)$ at room temperature and stained in an ethidium bromide solution of $0.5 \mu \mathrm{g} / \mathrm{ml}$.

Primer design and primer typing of aster yellows phytoplasma strains. The primers BF and BR (Table 1) were developed from a DNA band specific to AY-WB identified by random amplified polymorphic DNA (RAPD) analysis with primer OPH4 (Operon, Alameda, CA) using the same PCR program for primers $\mathrm{F} 4$ and $\mathrm{R} 1$, except the annealing temperature was $35^{\circ} \mathrm{C}$. DNA was extracted from sap of lettuce plants that were infected by different AYP strains. The $\approx 900$-bp band specific to AY-WB was cut from the gel, purified with the Qiagen gel extraction kit (Qiagen, Valencia, CA), and cloned to pGEM-T Easy Vector and sequenced with primers T7 and SP6. Primers BF and BR were designed based on the insert sequence. DNA extracts of Western $\mathrm{X}$ phytoplasma and beet leafhopper-transmitted virescence agents used as controls were provided by L. W. Liefting and B. C. Kirkpatrick (University of California, Davis). The primers S10F and S10R were developed from AY-S genomic DNA clones using the PCR-Script Amp Cloning Kit (Stratagene, La Jolla, CA) with

TABLE 1. Polymerase chain reaction (PCR) primers designed to differentiate aster yellows (group 16SrI) phytoplasma strains

\begin{tabular}{|c|c|c|c|}
\hline Primer ID & Primer sequence $\left(5^{\prime}\right.$ to $\left.3^{\prime}\right)$ & Product size (bp) & Sequences for primer design \\
\hline $015 \mathrm{~F}$ & AGGCGCAATAAAGATACCC & 786 & Insertion sequence \\
\hline $015 R$ & ACGCATCCAAGCTTTGTGTC & & \\
\hline $15 \mathrm{~F}$ & CCСТCAAACCCACGAAGTT & 390 & AY19p/AY19m PCR product \\
\hline $15 R$ & TACTGTGTTCCCTTACTCC & & \\
\hline $21 \mathrm{~F}$ & CCAATCATTTAGATAAAATTGATACC & 519 & AY19p/AY19m PCR product \\
\hline $21 \mathrm{R}$ & TGTAGTTGAGTTCTATGTAGC & & \\
\hline $\mathrm{BF}$ & AGGATGGAACCCTTCAATGTC & 900 & Genomic DNA \\
\hline $\mathrm{BR}$ & GGAAGTCGCCTACAAAAATCC & & \\
\hline S1 & CGCTAACAAATGTAAAGGCAAG & 493 & AY19p/AY19m PCR product \\
\hline $\mathrm{S} 2$ & CTTTAATAGGACTATGAGGG & & \\
\hline S10F & CCTAGCCCTACCAAAAGC & 386 & Genomic DNA \\
\hline S10R & CTGATTTAGGTGAGAAAATCC & & \\
\hline
\end{tabular}


DNA purified by pulse field gel electrophoresis (1\% agarose gel, $6 \mathrm{~V} / \mathrm{cm}$, switch time ramp 60 to $120 \mathrm{~s}$, and included angle of $120^{\circ}$ for $18 \mathrm{~h}$; CHEF-DR Bio-Rad PFGE system). The purified DNA was digested with $A l u \mathrm{I}$ and purified using a PCR purification kit (Qiagen) before ligation. The genomic DNA clones were selected as white colonies in IPTG-X-gal agar plates with ampicillin (29). The plasmid DNA was extracted using a Miniprep kit (Qiagen) and the insert was sequenced. Part of the insert sequence showed high sequence identity with an AL1-like protein gene (27). The primers $015 \mathrm{~F}$ and $015 \mathrm{R}$ were developed from genomic DNA sequences flanking a putative transposase coding region lacking inverted repeats. The sequencing was done at Integrated Genomics (Chicago). The other primers were designed based on PCR products amplified by AY19p and AY19m (Table 1).

Cloning and sequencing. Phytoplasma rRNA operon partial sequences were amplified with primers P1 and P7, purified using QIAquick PCR purification kit (Qiagen), and cloned with the pGEM-T vector systems (Promega Corp., Madison, WI). DNA of plasmids with inserts was extracted with a Miniprep kit (Qiagen), re-amplified with P1 and P7, and analyzed by RFLP with MspI. Two different RFLP banding patterns were observed in clones from three AYP strains, which putatively indicate $16 \mathrm{~S}$ genes from different rRNA operons in the phytoplasma genome (23); therefore, both clones were sequenced for the three strains. The inserts were sequenced using Sp6 and T7 primers targeting the promoter region flanking the multiple cloning sites and F4 and R4 (5'-CGA

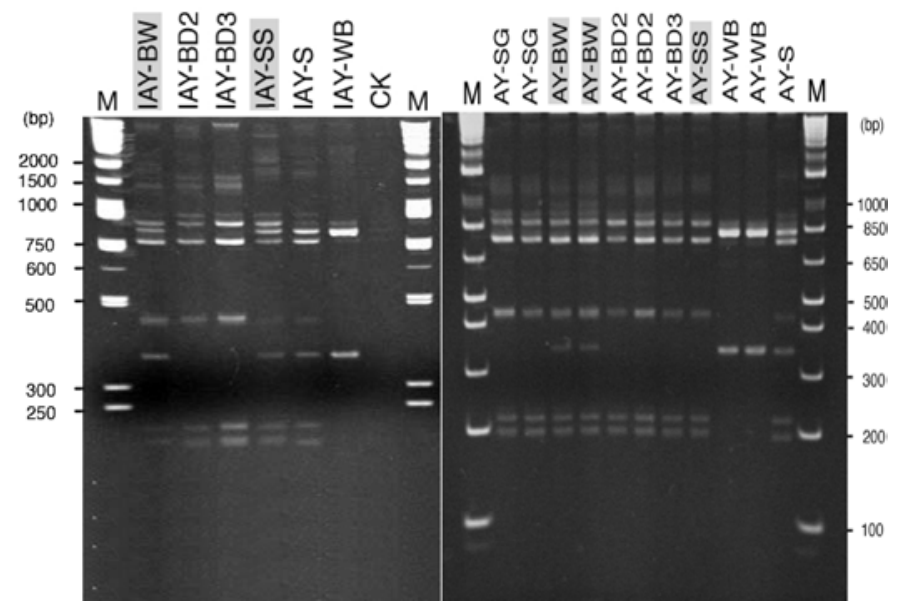

Fig. 1. Polymerase chain reaction (PCR) restriction fragment length polymorphism banding patterns of aster yellows (AY) phytoplasma isolates (left) and isolated strains (right). Lanes with the same name contain DNA extracts from different plants infected by the same strain. DNA was amplified by PCR using primers AY19p and AY19m and the PCR product was digested with DraI. Field isolates are designated with "I" preceding the name and isolated strains are: AY-Bolt white (AY-BW), AY-Bolt distortion strains-2 and -3 (AYBD2 and AY-BD3), AY-similar to severe (AY-SS), AY-severe (AY-S), AYwitches' broom (AY-WB), and AY-semi-geotropism (AY-SG). IAY-SG was run in a separate gel and is not shown here. $M=$ DNA ladder. Mixed isolates and the strains isolated from them are highlighted.
CAA CCA TGC ACC ACC TG-3') targeting the middle of the insert. The sequences were aligned and a contig was constructed for each clone that included the complete sequence of the P1/P7 amplicon.

Phylogenetic analyses. Seventeen $16 \mathrm{~S}$ rRNA genes from position 6 to 1,522 of 12 phytoplasmas and two Acholeplasma spp. were aligned with ClustalX 1.81 (14) with the following settings: pairwise alignment with slow and accurate, gap opening 10.0 and gap extension 5.0; and multiple alignment with gap opening 10.0 and gap extension 5.0. Nineteen sequences of $16 \mathrm{~S}-23 \mathrm{~S}$ gene spacer regions, including Acholeplasma brassicae, also were aligned. The alignments were adjusted manually (Study Accession no. S1086) and analyzed with the parsimony method using the computer program PAUP* (phylogenetic analysis using parsimony) software (version 4.0 for Macintosh; David Swofford, Sinauer Associates, Sunderland, MA). In the parsimony setting option, gaps were treated as missing data. Phylogenetic trees were constructed by a heuristic search (stepwise-addition options) and bootstrap values were from 100 bootstrap replications. The partial sequences of the rRNA operons of the AYP strains collected from lettuce were deposited in the GenBank nucleic acid sequence database under the following accession numbers: AY389819 (AY-SG), AY389820 (AY-BW), AY389821 (AY-S operon A), AY389822 (AY-BD2 operon A), AY389824 (AY-S operon B), AY389826 (AY-BD2 operon B), AY389827 (AY-WB operon A), and AY389828 (AY-WB 16S rRNA gene).

\section{RESULTS}

AYP strain isolation and PCR-RFLP analysis. Field AYP isolates IAY-witches'-broom (IAY-WB), IAY-bolt distortion-2 (IAY-BD2), IAY-bolt distortion-3 (IAY-BD3), IAY-semi-geotropism (IAY-SG), and IAY-severe (IAY-S) segregated in neither symptoms nor PCR-RFLP banding patterns during three rounds of isolation and were designated strains AY-WB, AY-BD2, AYBD3, AY-SG, and AY-S, respectively (Fig. 1). Strain AY-SS segregated from a severe-type symptom isolate (IAY-SS) after the second round of isolation. RFLP analysis of PCR products amplified with primers AY19p and AY19m showed that AY-SS strain lacks two bands (850 and $350 \mathrm{bp}$ ) that were present in IAY-SS. Similarly, AY-BW was isolated from field isolate IAY-BW after two rounds of transmission. PCR-RFLP analysis demonstrated that AY-BW lacks the 850-bp band that was present in IAY-BW. Strain AY-SS was lost during transfer and sufficient AY-BD3-infected plants were not available for symptom determination. Therefore, symptoms caused by these two strains are not described, although their molecular characteristics sometimes are mentioned along with those of other strains. Segregation of host symptoms and PCR-RFLP banding patterns were not observed in the isolated strains.

RFLP fingerprints of AY19p- and AY19m-amplified PCR products digested with DraI for AY-BW, AY-WB, and AY-S were unique (Fig. 1). However, AY-SG, AY-BD2, AY-BD3, and AY-SS were indistinguishable. The total molecular size of the digested

TABLE 2. Symptoms caused by different aster yellows phytoplasma strains in aster and lettuce plants, listed in order of occurrence

\begin{tabular}{|c|c|c|}
\hline Strain & Symptoms on aster & Symptoms on lettuce \\
\hline AY-WB & $\begin{array}{l}\text { Vein clearing, yellowing, abnormally upright growth of leaf petioles, stunting, } \\
\text { witches'- broom, pigment loss or sterility of flowers, necrosis }\end{array}$ & $\begin{array}{l}\text { Vein clearing, yellowing, stunting, wilting and necrosis in plants } \\
\text { infected at the early growth stage, bolting in plants infected at the } \\
\text { late growth stage, ooze }\end{array}$ \\
\hline AY-S & $\begin{array}{l}\text { Yellowing of emerging leaves, stunting, clustering of leaves, phyllody and } \\
\text { virescence }\end{array}$ & Yellowing, stunting, loss of leaf blades, ooze \\
\hline AY-BW & $\begin{array}{l}\text { Vein clearing, abnormally upright growth of leaf petioles, chlorosis, stunting, } \\
\text { flower sterility and loss of pigment }\end{array}$ & Bolting, abnormal leaf elongation, chlorosis, ooze \\
\hline AY-SG & $\begin{array}{l}\text { Vein clearing, abnormally upright growth of leaf petioles, yellowing, stunting, } \\
\text { stem bending (semi-geotropism), flower sterility }\end{array}$ & Vein clearing, yellowing, stem bending (semi-geotropism), ooze \\
\hline AY-BD2 & $\begin{array}{l}\text { Vein clearing, abnormally upright growth of leaf petioles, yellowing, } \\
\text { flower sterility }\end{array}$ & Bolting, light green coloration, distortion of stem and leaves, ooze \\
\hline
\end{tabular}


fragments of AY-WB was the same as the original PCR product $(1.1 \mathrm{~kb})$. However, the sum of the molecular weights of the digested fragments of the other strains was larger than the original PCR products, which suggests that these AYP genomes may contain two or more copies of the AY19p- or AY19m-amplified fragment with sequence differences. In addition, the primers designed based on the sequence alignment of the AY19p and AY19m products of different AYP strains were assumed to be strain-specific, but all generated the DNA fragment from the other strains, which indicates that the AYP strains contain more than one copy of the DNA fragment. Although it is possible that mixed isolates were not separated through the isolation cycling between vectors and plants, our unpublished data indicate that, in a dual mixed infection, either of the strains, but not both, could be detected by PCR-RFLP from the growing point of the same plant.

The PCR-RFLP banding pattern of the 1.2-kb DNA fragment amplified from extracts of infected lettuce with 16S rDNA primers $\mathrm{F} 2 \mathrm{n}$ and $\mathrm{R} 2$ were identical for three of four restriction enzymes tested for all AYP strains evaluated (data not shown).
Only the HhaI restriction pattern of AY-WB differed from that of the other strains, in the presence of one $\approx 310$-bp band and the absence of two smaller fragments $(\approx 150$ and $160 \mathrm{bp})$, which indicates that the PCR product of AY-WB has one HhaI restriction site while the others have two. Based on this difference, AY-WB was classified into the 16SrI-A subgroup and all the other strains were classified into 16SrI-B subgroup (22).

Host symptoms caused by the AYP strains. Aster yellows symptoms on China aster and lettuce plants are summarized in Table 2. The initial symptom caused by all the AYP strains except AY-S in aster was vein clearing, followed by abnormally upright growth of leaf petioles (Fig. 2). The other symptoms vary with strain and time of inoculation. Strains AY-BW, AY-WB, AY-BD2, and AY-SG caused the leaf petioles of aster to grow in an abnormally upright position, but AY-S caused stunting. Plant symptoms were more pronounced when they were inoculated at the 10- or 15-expanded-leaf stage than those inoculated at the 20-expandedleaf stage. Plants inoculated at the early growth stages did not produce flowers, whereas those inoculated at the 20-expanded-
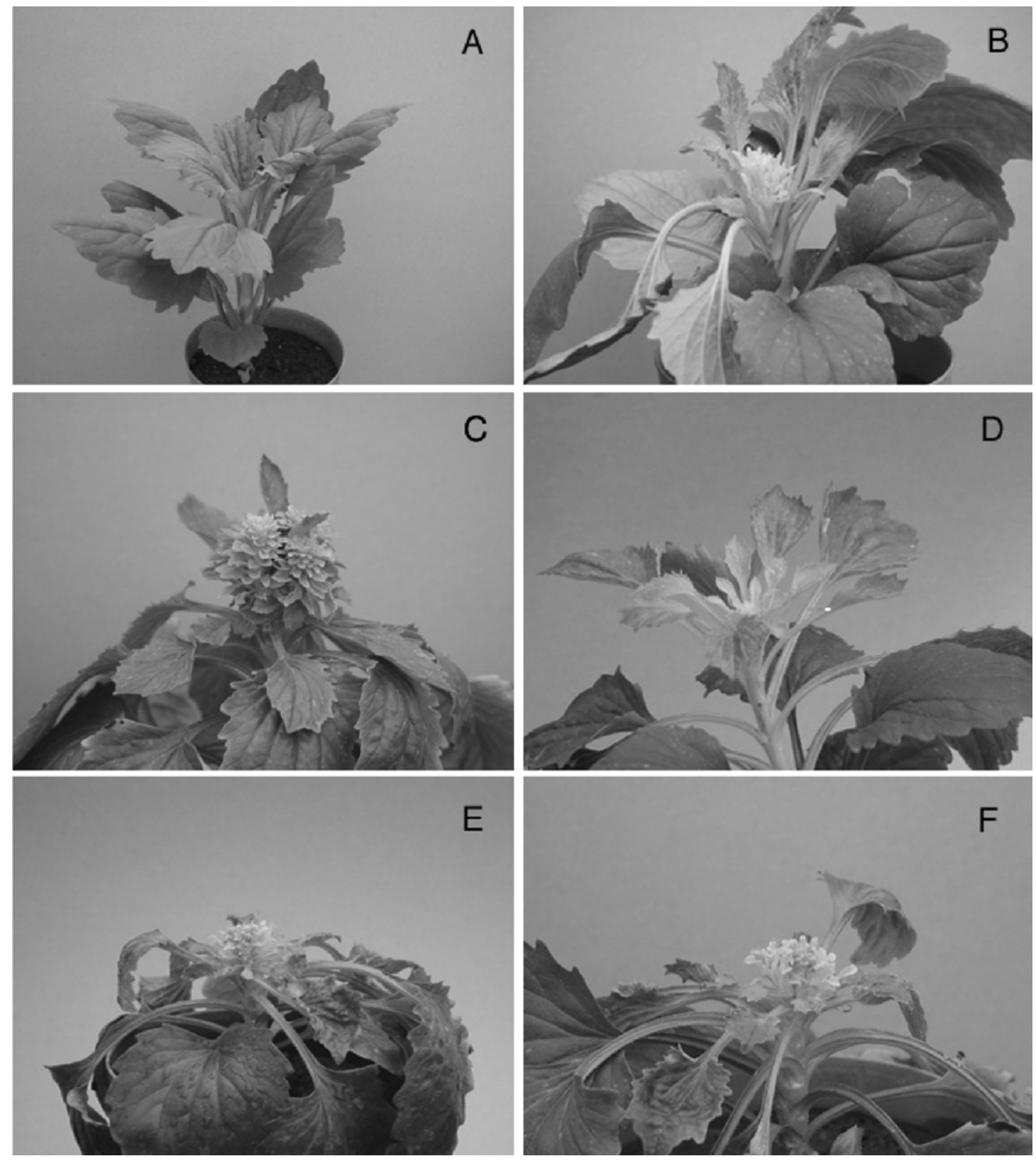

Fig. 2. Late-stage symptoms of aster plants infected by aster yellows (AY) phytoplasma strains from lettuce. A, Healthy aster, B, AY-WB (AY-witches'-broom), C, AY-S (AY-severe), D, AY-BW (AY-bolt white), E, AY-SG (AY-semi-geotropism), F, AY-BD2 (AY-bolt distortion-2). The plants were inoculated at the 10-expanded-leaf stage. 
leaf stage occasionally produced sterile flowers. Plants inoculated with AY-WB showed witches'-broom symptoms $\approx 6$ weeks after inoculation, followed by necrosis and plant death. Strain AY-S caused, in addition to chlorosis and stunting, clustering of leaves, phyllody, and virescence. Newly emerged leaves were chlorotic for a short period of time ( 2 to 3 days), then gradually became light to deep green and were smaller than leaves of healthy plants. Plants infected at the 20-expanded-leaf stage produced flowers, but their coronas became white to light green and leaf-shaped (phyllody) and sterile. Symptoms caused by strain AY-SG in China aster plants were similar to those caused by AY-S, except that fewer branches were observed. In addition, plants infected at the 15-expanded-leaf stage exhibited semi-geotropism (horizontal growth) at both the early and late stages of infection. Strain AYBW caused abnormally upright growth and chlorosis. Strain AYBD2 caused symptoms similar to those caused by AY-WB at the early stage of infection. Symptomatic leaves formed a cluster and became chlorotic, but witches'-broom symptoms were not observed in plants infected at the late growth stage.

In lettuce, all strains caused chlorosis and production of latexlike ooze droplets on leaf and stem surfaces at the late stage of infection. The ooze initially was milky white and darkened with time. Strain AY-WB caused vein-clearing followed by chlorosis, stunting, necrosis, bolting, and finally plant death. Plants infected early (eight-expanded-leaf stage) became chlorotic, beginning from emerging leaves and progressing to expanded leaves. Symptomatic leaves were smaller than healthy leaves. Infected plants wilted in sunlight but tended to recover at night. Strain AY-S significantly suppressed plant growth when the plants were infected at the early growth stage (data not shown). Infected plants produced progressively smaller leaves until leaf formation stopped. The color of newly emerged leaves was light green. The leaves were oriented in an abnormally upright position but the old leaves tended to flatten. AY-BW infection resulted in production of narrow, elongated, abnormally upright leaves. Plants infected at the early growth stage became chlorotic, whereas those infected at the late growth stage bolted. In lettuce plants infected with strain AY-SG, symptomatic leaves curled downward and growth was severely reduced. The stems and leaves of the plants infected at the late growth stage were deformed and showed semi-geotropism similar to that of aster plants infected at this stage. Leaves that emerged after infection by strain AY-BD2 were yellow and distorted. Leaves that expanded after infection were light green with vein clearing, whereas those that were fully expanded at the time of inoculation did not show symptoms. The symptoms were relatively mild compared with those caused by the other AYP strains.

Strain identification by primer typing. Five of seven AYP strains were differentiated using six pairs of primers in separate PCRs (primer typing). PCR with primers BF and BR generated a 900-bp fragment from AY-WB, but not from the other AYP strains, Western $\mathrm{X}$, grapevine yellows, or beet leafhopper-transmitted virescence agent, nor the DNA extracts of healthy leafhoppers, lettuce, carrot, or celery (Table 3). The primer pair $\mathrm{BF} / \mathrm{BR}$ was considered AY-WB specific although a weak, nonspecific 0.4-kb band was generated in AY-S using these primers.
Primers S1 and S2 generated a 493-bp DNA fragment from AYWB and AY-S (Table 3). Primers $15 \mathrm{~F}$ and $15 \mathrm{R}$ amplified a 390-bp DNA fragment from five AYP strains, except AY-WB and AY-S. Primers $21 \mathrm{~F}$ and $21 \mathrm{R}$ generated a 519-bp fragment from AY-BW, AY-BD2, AY-BD3, and AY-SG. Primers S10F and S10R generated a 380-bp PCR product from AY-BW, AY-BD3, AY-SG, and AY-S and primers $015 \mathrm{~F}$ and $015 \mathrm{R}$ generated a 786-bp PCR product from AY-BW, AY-SG, and AY-WB.

Phylogenetic analysis of 16S rRNA gene sequences. Based on phylogenetic analysis of the $16 \mathrm{~S}$ rRNA gene sequences, all the phytoplasmas from lettuce in Ohio were classified into one cluster that also includes AYP A 99UW111, Maryland aster yellows strain AY1, aster yellows western severe strain (SAY), Epilobium phyllody, clover phyllody, and tomato big bud (Arkansas strain). Bermudagrass white leaf phytoplasma, a member of $16 \mathrm{SrXIV}$ group, and western X, a member of 16 SrIII group, were separated from the cluster (Fig. 3). The results further indicated that the Ohio lettuce phytoplasmas were members of the aster yellows group, in which three subclusters were delineated. Two 16S rRNA genes of AY-WB, tomato big bud phytoplasmas (Arkansas strain) and AYP A isolate 99UW111, were in one subcluster, although formation of the subcluster was less certain as suggested by its bootstrapping value. All members in the subcluster belong to the 16SrI-A subgroup according to PCR-RFLP. The other AYP strains from Ohio lettuce clustered with members of the 16SrI-B subgroup. Two 16S rRNA gene sequences from different operons of clover phyllody strain $\mathrm{CPh}$ (16SrI-C) were separated from members of $16 \mathrm{SrI}-\mathrm{B}$. For the three Ohio lettuce AYP strains with two different $16 \mathrm{~S}$ rRNA operons partially sequenced, the two 16S rRNA gene sequences of the same strain shared 99.6 to $99.7 \%$ sequence identity and were grouped in the same subcluster. These sequences had higher sequence identity with each other than with sequences from strains in other subgroups and, thus, did not cause distortion of subgroups assigned according to PCR-RFLP.

Phylogenetic analysis of 16S-23S rDNA spacer regions. The phylogenetic tree constructed with the $16 \mathrm{~S}-23 \mathrm{~S}$ spacer regions showed that all the phytoplasmas from Ohio lettuce clustered into the same group with phytoplasmas in the aster yellows group from the GenBank database. Three subclusters were identified in the group. Two 16S-23S rRNA gene spacer regions from two separate rRNA operons of clover phyllody strain $\mathrm{CPh}$ were classified into one subcluster. AY-WB clustered with AYP A 99UW111 and Aconitum proliferation of the 16SrI-A subgroup, and an AYP Queen Anne's lace isolate. Other strains from Ohio lettuce formed a subcluster with AYPs of the 16SrI-B subgroup with low certainty (Fig. 4). This result is congruent with that inferred by PCR-RFLP of the $16 \mathrm{~S}$ rDNA and the phylogenetic analysis of the $16 \mathrm{~S}$ rRNA genes.

\section{DISCUSSION}

As reported for other plant species (7-9,18,21,22,32,34), more than one AYP strain may infect a lettuce plant in production fields. Because phytoplasma species or strains usually are identi-

TABLE 3. Differentiation of aster yellows phytoplasma strains collected from lettuce using different sets of primers ${ }^{\mathrm{a}}$

\begin{tabular}{|c|c|c|c|c|c|c|c|c|}
\hline \multirow[b]{2}{*}{ Primers } & \multicolumn{7}{|c|}{ Aster yellows phytoplasma strains } & \multirow[b]{2}{*}{ Healthy lettuce } \\
\hline & AY-BW & AY-BD2 & AY-BD3 & AY-SS & AY-SG & AY-WB & AY-S & \\
\hline $015 \mathrm{~F} / 015 \mathrm{R}$ & + & - & - & - & + & + & - & - \\
\hline $15 \mathrm{~F} / 15 \mathrm{R}$ & + & + & + & + & + & - & - & - \\
\hline $21 \mathrm{~F} / 21 \mathrm{R}$ & + & + & + & - & + & - & - & - \\
\hline $\mathrm{BF} / \mathrm{BR}$ & - & - & - & - & - & + & $-^{\mathrm{b}}$ & - \\
\hline $\mathrm{S} 1 / \mathrm{S} 2$ & - & - & - & - & - & + & + & - \\
\hline S10F/S10R & + & - & + & - & + & - & + & - \\
\hline
\end{tabular}

a DNA extracted from healthy lettuce was used as a negative control. Samples without amplification, -; strains with amplification, +.

b A weak, nonspecific $0.4-\mathrm{kb}$ band was generated. 
fied based on host symptoms or molecular markers, and a mixed infection can alter host symptoms and complicate molecular identification, strain isolation may be necessary. We demonstrated that a series of 12-h AAP and IAP for the leafhoppers allowed isolation of phytoplasma strains. The short AAP ensured that leafhoppers acquired as few phytoplasma cells as possible and the short IAP limited opportunities for leafhoppers to inject phytoplasma cells into the host plant. Purity of the AYP strains was monitored and verified by both segregation of host symptoms and PCR-RFLP analysis during the purification process.
In addition to the Bolt (AY-BD2) and Severe (AY-S) strains that had been reported in lettuce (26), at least five other strains are involved in epidemics of aster yellows in Ohio. Strain AY-WB caused symptoms similar to AY-BD2 in China aster at an early stage of infection, but the former caused witches'-broom in aster at later stages of infection whereas the latter did not. In lettuce, AY-WB caused wilting but AY-BD2 caused mild chlorosis and leaf distortion in plants at the early growth stage. Furthermore, AY-WB belongs to 16SrI-A subgroup and AY-BD2 belongs to 16SrI-B subgroup. Strain AY-SG caused symptoms typical of

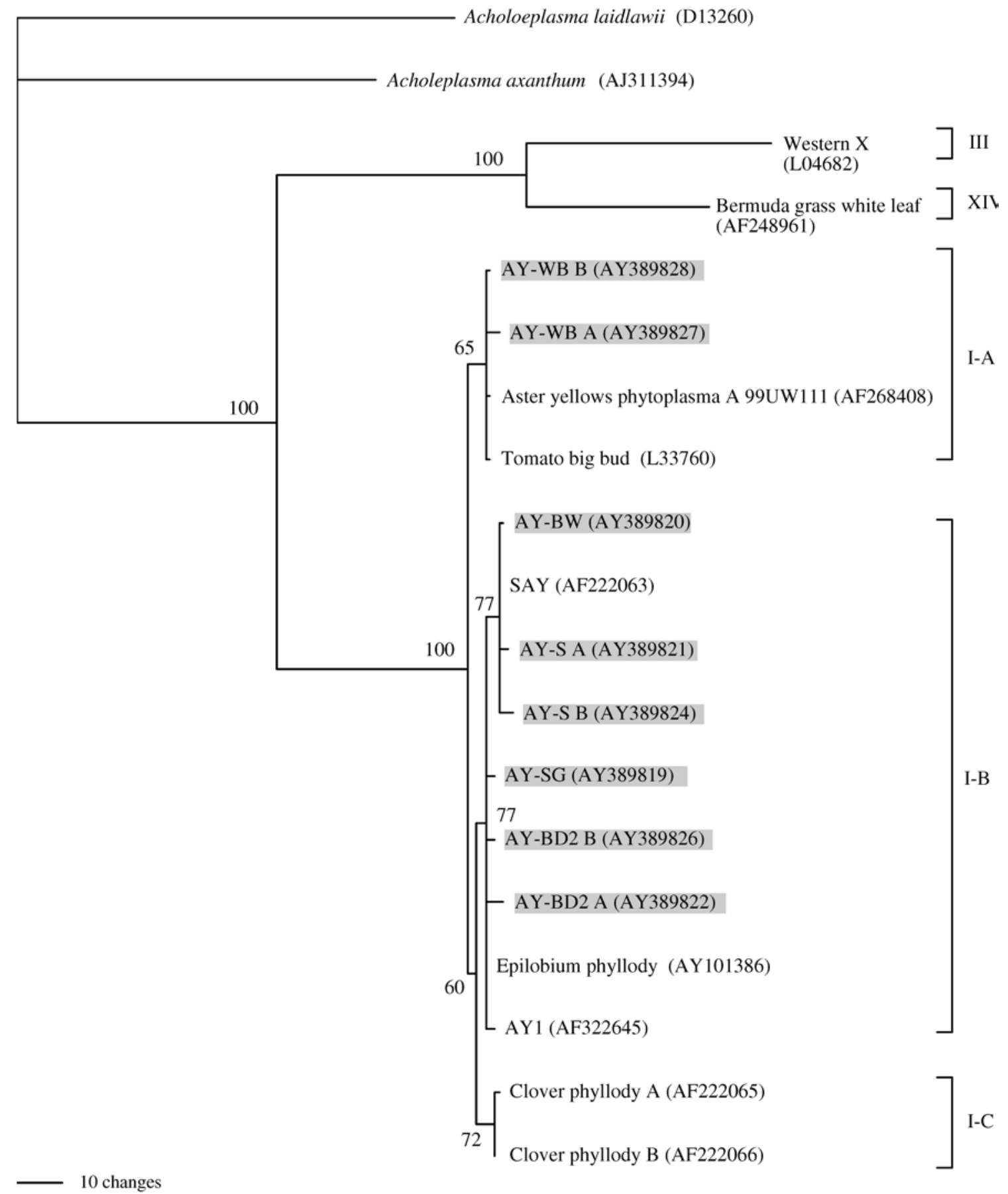

Fig. 3. Phylogenetic analysis of phytoplasma 16S rRNA gene sequences. Phytoplasma groups are indicated by Roman numerals and subgroups by capital letters. The 16S rRNA gene sequences used for the phylogenetic analysis are from aster yellows strain AY-BD2 rRNA operon A, Maryland aster yellows strain AY1 rRNA operon B, Epilobium phyllody, AY-SG, AY-S rRNA operon A, aster yellows western severe strain SAY, AY-BW, AY-S operon B, AY-BD2 rRNA operon B, AY-WB rRNA operon A, aster yellows phytoplasma A isolate 99UW111, tomato big bud (Arkansas strain), AY-WB 16S rRNA gene (AY-WB B), clover phyllody strain $\mathrm{CPh}$ rRNA operon A, clover phyllody strain $\mathrm{CPh}$ rRNA operon B, Bermudagrass white leaf phytoplasma, western X-disease, Acholeplasma axanthum strain 118, and A. laidlawii. Aster yellows strains from Ohio lettuce are highlighted. Bootstrap values are from 100 bootstrap repetitions. Only bootstrap values greater than 50 are shown. GenBank accession numbers are in parentheses to the right of the phytoplasma names. 
aster yellows western strain in China aster $(3,16)$. The symptoms caused by AY-S matched those of the original Ohio strain Severe and partially matched the symptoms (stunting and phyllody) of AY-OC1, considered to be a western strain (7), but AY-S did not cause elongation of internodes in aster plants. AY-SS caused symptoms similar to those caused by AY-S in aster plants but they had different fingerprints in PCR-RFLP and were amplified by different primers. The symptoms caused by strain AY-BW did not match those caused by any of the AYP strains reported in the literature to our knowledge.
Phylogenetic analysis of the 16S rRNA genes and 16S-23S gene spacer regions demonstrated that the phytoplasma strains collected from lettuce in Ohio are phytoplasmas in the 16SrI group and they were further delineated into two subgroups or clusters, which are consistent with PCR-RFLP of the 16S rDNA $(15,19,22,31)$. We also found that the 16S rRNA genes from two different rRNA operons in the same strain clustered together, which means that the sequence difference between the two $16 \mathrm{~S}$ rRNA genes from one genome is smaller than that among phytoplasma species or strains from different subgroups used in the

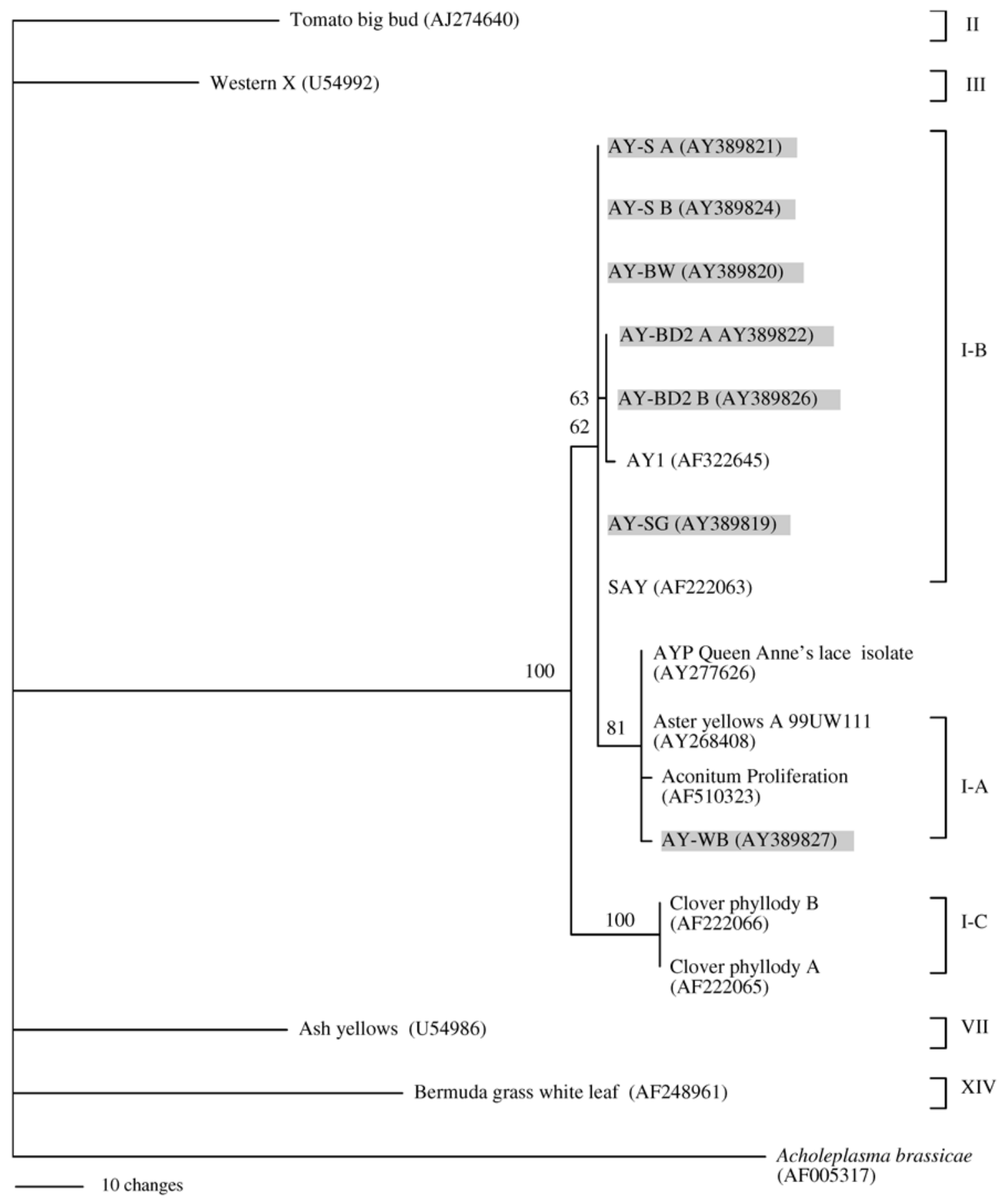

Fig. 4. Phylogenetic analysis of sequences of phytoplasma 16S-23S spacer regions. Phytoplasma groups are indicated by Roman numerals and subgroups by capital letters. The 16S-23S gene spacer regions used for the phylogenetic analysis are from tomato big bud phytoplasma (Australian strain), western $\mathrm{X}$ phytoplasma, ash yellows phytoplasma, Bermudagrass white leaf phytoplasma, AY-BW, AY-S rRNA operon A, AY-SG, AY-S rRNA operon B, AY-BD2 rRNA operon B, AY-BD2 rRNA operon A, Maryland aster yellows strain AY1 rRNA operon B, aster yellows western severe strain SAY, aster yellows phytoplasma Queen Anne's lace isolate, aster yellows A isolate 99UW111, AY-WB, Aconitum proliferation phytoplasma, clover phyllody strain CPh rRNA operon B, clover phyllody strain CPh rRNA operon A, and Acholeplasma brassicae. Aster yellows strains from Ohio lettuce are highlighted. Bootstrap values are from 100 bootstrap repetitions. Only bootstrap values greater than 50 are shown. GenBank accession numbers are in parentheses to the right of the phytoplasma names. 
phylogenetic analysis. This result suggests that the existence of two rRNA operons in each phytoplasma genome may not cause distortion in the phylogenetic analysis based on 16S rRNA gene sequences as suggested previously $(23,28,33)$. The phylogenetic tree based on the sequences of the $16 \mathrm{~S}-23 \mathrm{~S}$ spacer regions also showed that AYP strains from Ohio lettuce clustered in one group with other phytoplasmas in the $16 \mathrm{SrI}$ group. Even though the sequence of the $16 \mathrm{~S}-23 \mathrm{~S}$ gene spacer region is considered more variable than that of the 16S rRNA gene among phytoplasmas $(12,24)$, sequence differences between the two rRNA operons also were not sufficient to influence the phylogenetic classification.

Only primers BF and BR resulted in generation of a 900-bp band for AY-WB. These primers were derived from a cloned genomic DNA fragment generated by RAPD from AY-WB, the only AYP strain from lettuce in the 16SrI-A subgroup. Use of the remaining primers resulted in PCR products from at least two AYP strains. However, five of seven AYP strains were distinguished from one another by primer typing. Primer typing may be used to distinguish multiple AYP strains in lettuce production fields, whether in leafhoppers or in infected plants, which may lead to a better understanding of the epidemiology of this disease and refinement of predictive models.

\section{ACKNOWLEDGMENTS}

This work was supported by State and Federal funds appropriated to the Ohio Agricultural Research and Development Center, The Ohio State University. We thank M. L. Lewis Ivey and S. Gordon for presubmission reviews of this manuscript and helpful suggestions.

\section{LITERATURE CITED}

1. Beanland, L., Hoy, C. W., Miller, S. A., and Nault, L. R. 2000. Influence of aster yellows phytoplasma on the fitness of aster leafhopper (Homoptera: Cicadellidae). Ann. Entomol. Soc. Am. 93:271-276.

2. Chiykowski, L. N. 1977. Reduction in the transmissibility of a greenhouse-maintained isolate of aster yellows agent. Can. J. Bot. 55:17-21.

3. Chiykowski, L. N. 1987. Aster yellows in strawberry. Pages 31-34 in: Virus Diseases of Small Fruits. R. H. Converse, ed. U.S. Gov. Print. Office, Washington, DC.

4. Chiykowski, L. N., and Chapman, R. K. 1965. Migration of the sixspotted leafhopper in central North America. Wis. Agric. Exp. Stn. Res. Bull. 261:21-45.

5. Davis, R. E., and Lee, I.-M. 1993. Cluster-specific polymerase chain reaction amplification of 16S rDNA sequences for detection and identification of mycoplasmalike organisms. Phytopathology 83:1008-1011.

6. Drake, D. C., and Chapman, R. K. 1965. Evidence for long distance migration of the six-spotted leafhopper in Wisconsin. Wis. Agric. Exp. Stn. Res. Bull. 261:3-20.

7. Errampalli, D., and Fletcher, J. 1991. Incidence of yellows in carrot and lettuce and characterization of mycoplasmalike organism isolates in Oklahoma. Plant Dis. 6:579-584.

8. Errampalli, D., Fletcher, J., and Fastman, C. 1986. Natural occurrence of aster yellows in vegetable crop in Oklahoma. (Abstr.) Phytopathology 76:1084.

9. Freitag, J. H. 1964. Interaction and mutual suppression among three strains of aster yellows virus. Virology 24:401-413.

10. Gold, R. E., and Sylvester, E. S. 1982. Pathogen strains and leafhopper species as factors in the transmission of Western X-disease agent under varying light and temperature conditions. Hilgardia 50:1-43.

11. Gundersen, D. E., and Lee, I.-M. 1996. Ultrasensitive detection of phytoplasmas by nested-PCR assays using universal primer pairs, Phytopathol. Mediterr. 35:144-151.

12. Gundersen, D. E., Lee, I.-M., Rehner, S. A., Davis, R. E., and Kingsbury, D. T. 1994. Phylogeny of mycoplasmalike organisms (phytoplasmas): A basis for their classification. J. Bacteriol. 176:5244-5254.

13. Hoy, C. W., Heady, S. E., and Koch, T. A. 1992. Species composition, phenology and possible origins of leafhoppers (Cicadellidae) in Ohio vegetable crops. J. Econ. Entomol. 85:2336-2343.

14. Jeanmougin, F., Thompson, J. D., Gouy, M., Higgind, D. G., and Gibson, T. J. 1998. Multiple sequence alignment with Clustal X. Trends Biochem. Sci. 23:403-405

15. Jung, H.-Y., Sawayanagi, T., Kakizawa, S., Nishigawa, H., Miyata, S., Oshima, K., Ugaki, M., Lee, J.-T. Hibi, T., and Namba, S. 2002. Candidatus phytoplasma taxon associated with chestnut witches' broom dis- eases. Int. J. Syst. Environ. Microbiol. 52:1543-1549.

16. Kunkel, L. O. 1955. Cross protection between strains of yellows-type viruses. Adv. Virus Res. 3:251-273.

17. Kuske, C. R., and Kirkpatrick, B. C. 1992. Phylogenetic relationships between the western aster yellows mycoplasmalike organisms and other prokaryotes established by $16 \mathrm{~S}$ rRNA gene sequence. Int. J. Syst. Bacteriol. 42:226-233.

18. Lee, I.-M., Bertaccini, A., Vibio, M., and Gundersen, D. E. 1995. Detection of multiple phytoplasmas in perennial fruit trees with decline symptoms in Italy. Phytopathology 85:728-735.

19. Lee, I.-M., Davis, R. E., Chen, T. A., Chiykowski, L. N., Fletcher, J., Hiruki, C., and Schaff, D. A. 1992. A genotype-based system for identification and classification of mycoplasmalike organisms (MLOs) in the aster yellows MLO strain cluster. Phytopathology 82:977-986.

20. Lee, I.-M., Davis, R. E., and Gundersen-Rindal, D. E. 2000. Phytoplasma: Phytopathogenic mollicutes. Annu. Rev. Microbiol. 54:221-255.

21. Lee, I.-M., Gundersen, D. E., Hammond, R. W., and Davis, R. E. 1994. Use of mycoplasmalike organism (MLO) group-specific oligonucleotide primers for nested-PCR assays to detect mixed-MLO infections in a single host plants. Phytopathology 84:559-566.

22. Lee, I.-M., Hammond, R. W., Davis, R. E., and Gundersen, D. E. 1993. Universal amplification and analysis of pathogen 16S rDNA for classification and identification of mycoplasmalike organisms. Phytopathology 83:834-843.

23. Liefting, L. W., Andersen, M. T., Beever, R. E., Gardner, R. C., and Forster, R. L. S. 1996. Sequence heterogeneity in the two 16S rRNA genes of Phormium yellow leaf phytoplasma. Appl. Environ. Microbiol. 62:3133-3139.

24. Marcone, C., Lee, I.-M., Davis, R. E., Ragozzino, A., and Semüller, E. 2000. Classification of aster yellows-group phytoplasmas based on combined analyses of rRNA and tuf gene sequences. Int. J. Syst. Environ. Microbiol. 50:1703-1713.

25. McCoy, R. E., Caudwell, A., Chang, C. J., Chen, T. A., Chiykowski, L. N., Cousin, M. T., Dale, J. L., de Leeuw, G. T. N., Golino, D. A., Hackett, K. J., Kirkpatrick, B. C., Marwitz, R., Petzold, H., Sinha, R. C., Sugiura, M., Whitcomb, R. F., Yang, I. L., Zhu, B. M., and Seemüller, E. 1989. Plant diseases associated with mycoplasma-like organisms. Pages 545640 in: The Mycoplasmas, Vol. 5. R. F. Whitecomb and J. G. Tully, eds. Academic Press, New York.

26. Murral, D. J., Nault, L. R., Hoy, C. W., Madden, L., and Miller, S. A. 1996. Effects of temperature and vector age on transmission of two Ohio strains of aster yellows phytoplasma by the aster leafhopper (Homoptera: Cicadellidae). J. Econ. Entomol. 89:1223-1232.

27. Orozco, B. M., and Hanley-Bowdoin, L. 1998. Conserved sequence and structural motifs contribute to the DNA binding and cleavage activities of a geminivirus replication protein. J. Biol. Chem. 273:24448-24456.

28. Oshima, K., Miyata, S., Sawayanagi, T., Kakizawa, S., Nishigawa, H., Jung, H., Furuki, K., Yanazaki, M., Suzuki, S., Wei, W., Kuboyamy, T., Ugaki, M., and Namba, S. 2002. Minimal set of metabolic pathways suggested from the genome of onion yellows phytoplasma. J. Gen. Plant Pathol. 68:225-236.

29. Sambrook, J., Fritsch, E. F., and Maniatis, T. 1989. Molecular Cloning: A Laboratory Manual. Cold Spring Harbor Laboratory, Cold Spring Harbor, NY.

30. Schaff, D., Lee, I.-M., and Davis, R. E. 1992. Sensitive detection and identification of mycoplasma-like organisms in plants by polymerase chain reactions. Biochem. Biophys. Res. Commun. 186:1503-1509.

31. Schneider, B., Marcone, C., Kampmann, M., Ragozzino, A., Lederer, W., Cousin, M.-T., and Seemüller, E. 1997. Characterization and classification of phytoplasmas from wild and cultivated plants by RFLP and sequence analysis of ribosomal DNA. Eur. J. Plant Pathol. 103:675-686.

32. Schneider, B., Padovan, A., De La Rue, S., Sdoodee, R., Suseno, R., Mutaqin, K., Lum, K. Y., Davis, R., Eichner, R., and Gibb, K. S. 1998. Detection and characterization of phytoplasmas in Australian and Southeast Asia. Page 65 in: Abstr. 12th Int. Organ. Mycoplasmol. Conf. Sydney, Australia.

33. Schneider, B., and Seemüller, E. 1994. Presence of two sets of ribosomal genes in phytopathogenic mollicutes. Appl. Environ. Microbiol. 60:34093412.

34. Sinclair, W. A., and Griffiths, H. M. 2000. Variation in aggressiveness of strains of ash yellows phytoplasmas. Plant Dis. 84:282-288.

35. Smart, C. D., Schneider, B., Blomquist, C. L., Guerra, L. J., Harrison, N. A., Aherens, U., Lorenz, K.-H., Seemüller, E., and Kirkpartrick, B. C. 1996. Phytoplasma-specific PCR primers based on sequences of the 16S23S rRNA spacer region. Appl. Environ. Microbiol. 62:2988-2993.

36. Zhang, Y.-P., Uyemoto, J. K., and Kirkpatrick, B. C. 1998. A small-scale procedure for extracting nucleic acids from woody plants infected with various phytopathogens for PCR assay. J. Virol. Methods 71:45-50.

37. Zhou, X., Hoy, C. W., Miller, S. A., and Nault, L. R. 2002. Spatially explicit simulation of aster yellows epidemics and control on lettuce. Ecol. Model. 151:293-307. 